\title{
Constraints on Asian ozone using Aura TES, OMI and Terra MOPITT
}

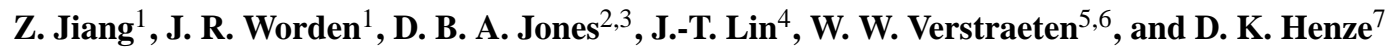 \\ ${ }^{1}$ Jet Propulsion Laboratory, California Institute of Technology, Pasadena, CA, USA \\ ${ }^{2}$ Department of Physics, University of Toronto, Toronto, ON, Canada \\ ${ }^{3}$ JIFRESSE, University of California, Los Angeles, Los Angeles, CA, USA \\ ${ }^{4}$ Laboratory for Climate and Ocean-Atmosphere Studies, Department of Atmospheric and Oceanic Sciences, School of \\ Physics, Peking University, Beijing, China \\ ${ }^{5}$ Meteorology and Air Quality Department, Wageningen University, the Netherlands \\ ${ }^{6}$ Climate Observations Department, Royal Netherlands Meteorological Institute, the Netherlands \\ ${ }^{7}$ Department of Mechanical Engineering, University of Colorado, Boulder, CO, USA
}

Correspondence to: Z. Jiang (zhe.jiang@jpl.nasa.gov)

Received: 25 June 2014 - Published in Atmos. Chem. Phys. Discuss.: 29 July 2014

Revised: 13 November 2014 - Accepted: 24 November 2014 - Published: 8 January 2015

\begin{abstract}
Rapid industrialization in Asia in the last two decades has resulted in a significant increase in Asian ozone $\left(\mathrm{O}_{3}\right)$ precursor emissions with likely a corresponding increase in the export of $\mathrm{O}_{3}$ and its precursors. However, the relationship between this increasing $\mathrm{O}_{3}$, the chemical environment, $\mathrm{O}_{3}$ production efficiency, and the partitioning between anthropogenic and natural precursors is unclear. In this work, we use satellite measurements of $\mathrm{O}_{3}, \mathrm{CO}$ and $\mathrm{NO}_{2}$ from TES (Tropospheric Emission Spectrometer), MOPITT (Measurement of Pollution In The Troposphere) and OMI (Ozone Monitoring Instrument) to quantify $\mathrm{O}_{3}$ precursor emissions for 2006 and their impact on free tropospheric $\mathrm{O}_{3}$ over northeastern Asia, where pollution is typically exported globally due to strong westerlies. Using the GEOSChem (Goddard Earth Observing System Chemistry) global chemical transport model, we test the modeled seasonal and interannual variation of $\mathrm{O}_{3}$ based on prior and updated $\mathrm{O}_{3}$ precursor emissions where the updated emissions of $\mathrm{CO}$ and $\mathrm{NO}_{\mathrm{x}}$ are based on satellite measurements of $\mathrm{CO}$ and $\mathrm{NO}_{2}$. We show that the observed TES $\mathrm{O}_{3}$ variability and amount are consistent with the model for these updated emissions. However, there is little difference in the modeled ozone between the updated and prior emissions. For example, for the 2006 June time period, the prior and posterior $\mathrm{NO}_{\mathrm{x}}$ emissions were $14 \%$ different over China but the modeled ozone in the free troposphere was only $2.5 \%$ different. Using the ad-
\end{abstract}

joint of GEOS-Chem we partition the relative contributions of natural and anthropogenic sources to free troposphere $\mathrm{O}_{3}$ in this region. We find that the influence of lightning $\mathrm{NO}_{\mathrm{x}}$ in the summer is comparable to the contribution from surface emissions but smaller for other seasons. China is the primary contributor of anthropogenic $\mathrm{CO}$, emissions and their export during the summer. While the posterior $\mathrm{CO}$ emissions improved the comparison between model and TES by $32 \%$, on average, this change also had only a small effect on the free tropospheric ozone. Our results show that the influence of India and southeastern Asia emissions on $\mathrm{O}_{3}$ pollution export to the northwestern Pacific is sizeable, comparable with Chinese emissions in winter, about $50 \%$ of Chinese emissions in spring and fall, and approximately $20 \%$ of the emissions in the summer.

\section{Introduction}

Unprecedented growth in transportation, coal-fired power plants and the industrial sector in China has resulted in a substantial increase in the emissions of $\mathrm{O}_{3}$ precursors (Lin et al., 2014a). Recent studies (Lamsal et al., 2011; Lin, 2012; Mijling et al., 2013) show a 5-10\% annual growth rate of $\mathrm{NO}_{\mathrm{x}}$ emission in China. Wang et al. (2012) found there was a $3 \%$ annual growth rate of $\mathrm{O}_{3}$ in Beijing in the period of 
2003-2010. East Asian $\mathrm{O}_{3}$ can be transported to the surface of North America in about 2-3 weeks (Liu and Mauzerall, 2005) by midlatitude westerly winds (Liang et al., 2004, 2005), which likely resulted in an increase of background $\mathrm{O}_{3}$ concentration in western North America by 3-7 ppbv (parts per billion by volume) during the period of 2000-2006 (Zhang et al., 2008; Brown et al., 2011).

Use of inverse (top-down) methods to better quantify the emission of $\mathrm{NO}_{\mathrm{x}}$ (Lamsal et al., 2011; Lin and McElroy, 2011; Lin, 2012; Mijling et al., 2013), VOCs (volatile organic compounds; Shim et al., 2005; Fu et al., 2007) and CO (Kopacz et al., 2010; Fortems-Cheiney et al., 2011; Gonzi et al., 2011) are needed to ensure consistency between bottomup inventories and observations. However, large discrepancies can still exist between bottom-up- and top-down-based inventories (e.g., Kopacz et al., 2010; Lin et al., 2012). In this work, we perform a multi-tracer assimilation with the GEOSChem (Goddard Earth Observing System Chemistry) model to evaluate the top-down estimates of $\mathrm{O}_{3}$ precursors $\left(\mathrm{NO}_{\mathrm{x}}\right.$ and $\mathrm{CO}$ ) in eastern Asia. We firstly optimized the $\mathrm{CO}$ and $\mathrm{NO}_{\mathrm{x}}$ emission with MOPITT (Measurements Of Pollution In The Troposphere) CO and OMI (Ozone Monitoring Instrument) $\mathrm{NO}_{2}$ retrievals, respectively, and then evaluate the a posteriori simulation of $\mathrm{CO}$ and $\mathrm{O}_{3}$ by comparing the values with measurements from TES (Tropospheric Emission Spectrometer) in the period of December 2005-November 2006. Using the adjoint of the GEOS-Chem model (Henze et al., 2007), we then quantify source contributions $\left(\mathrm{NO}_{\mathrm{x}}, \mathrm{CO}\right.$, VOC) to free tropospheric $\mathrm{O}_{3}$ pollution over eastern China and the China outflow region in December 2005-November 2006.

\section{Observations and model}

\subsection{TES CO and $\mathrm{O}_{3}$}

The TES instrument was launched on NASA's Aura spacecraft on 15 July 2004. The satellite is in a sun-synchronous polar orbit of $705 \mathrm{~km}$ and crosses the Equator at 01:45 and 13:45 LT (local time). With a footprint of $8 \mathrm{~km} \times 5 \mathrm{~km}$, TES measures radiances between 3.3 and $15.4 \mu \mathrm{m}$ with a global coverage in 16 days (Beer et al., 2001) of observations. In the troposphere, TES $\mathrm{O}_{3}$ profile retrievals have 1-2 degrees of freedom for signal (DOFS), and about 1 DOFS for CO. We use data from the "lite" product (http://tes.jpl.nasa.gov/data/) which reports volume mixing ratios (VMRs) on 26 pressure levels for $\mathrm{O}_{3}$ and 14 pressure levels for $\mathrm{CO}$. Using an optimal estimation approach, the TES retrievals are conducted with respect to the logarithm of the VMR. The relationship between the retrieved profiles and the true atmospheric state can be expressed as

$\hat{z}^{\mathrm{TES}}=z_{\mathrm{a}}^{\mathrm{TES}}+\mathbf{A}^{\mathrm{TES}}\left(z-z_{\mathrm{a}}^{\mathrm{TES}}\right)+\mathbf{G} \varepsilon$, where $z$ is the true atmospheric state (expressed as $\log (\mathrm{VMR})), \mathbf{z}_{\mathrm{a}}^{\mathrm{TES}}$ is the TES a priori $\mathrm{O}_{3}$ or $\mathrm{CO}$ profile, $\mathbf{A}^{\mathrm{TES}}$ is the TES averaging kernel matrix and $\mathbf{G} \varepsilon$ describes the retrieval error. The averaging kernel matrix represents the sensitivity of the retrieval to the actual trace gas in the atmosphere. The TES retrievals use a monthly mean profile of the trace gas from the MOZART-4 CTM (chemical transport model), averaged over a $10^{\circ}$ latitude $\times 60^{\circ}$ longitude, as the a priori information $z_{\mathrm{a}}^{\mathrm{TES}}$. According to the recommended quality control criterion, we only use $\mathrm{CO}$ and $\mathrm{O}_{3}$ data with major quality flags of 1 . These data have passed all major quality flags used to assess the TES data related to chi-2 tests, biases in the radiance residuals, and residual nonlinearity checks. The data with small DOFS (DOFS for CO smaller than 0.8 ) are dropped as the limited sensitivity reduces the robustness of calculated $\mathrm{O}_{3}-\mathrm{CO}$ correlations. We empirically find that the sensitivity of $\mathrm{CO}$ is the limiting factor in these comparisons; that is, if DOFS for CO is $>0.8$ then the DOFS of $\mathrm{O}_{3}$ is $>0.8$. Recently, Verstraeten et al. (2013) evaluated TES $\mathrm{O}_{3}$ measurements by using data from the World Ozone and Ultraviolet Radiation Data Centre (WOUDC) sites and found that there is $\mathrm{a} \sim 7 \mathrm{ppb}$ bias in the TES measurements in free troposphere, and that the magnitude is slightly larger in summer and smaller in winter. TES CO measurements were evaluated by Luo et al. (2007) using the aircraft measurements from INTEX-B (Intercontinental Chemical Transport Experiment B) campaign. They showed that TES CO VMR profiles are $0-10 \%$ lower than the aircraft measurements in the lower and middle troposphere.

\subsection{MOPITT CO}

The MOPITT instrument was launched on NASA's Terra spacecraft on 18 December 1999. The satellite is in a sunsynchronous polar orbit of $705 \mathrm{~km}$ and crosses the Equator at 10:30 LT. With a footprint of $22 \mathrm{~km} \times 22 \mathrm{~km}$, MOPITT (version 6) combines TIR (thermal infrared; $4.7 \mu \mathrm{m}$ ) with the NIR (near infrared; $2.3 \mu \mathrm{m}$ ) and has better sensitivity to lower tropospheric CO over land (Worden et al., 2010). MOPITT CO retrievals are reported on 10 pressure levels (surface, 900, $800,700,600,500,400,300,200$ and $100 \mathrm{hPa}$ ). Similar to the TES product, relationship between the retrieved $\mathrm{CO}$ profiles and the true atmospheric state can be expressed as

$z^{\mathrm{MOP}}=z_{\mathrm{a}}^{\mathrm{MOP}}+\mathbf{A}^{\mathrm{MOP}}\left(z-z_{\mathrm{a}}^{\mathrm{MOP}}\right)+\mathbf{G} \varepsilon$,

where $z$ is the true atmospheric state (expressed as $\log (\mathrm{VMR})), z_{\mathrm{a}}^{\mathrm{MOP}}$ is the MOPITT a priori CO profile, $\mathbf{A}^{\mathrm{MOP}}$ is the MOPITT averaging kernel matrix and $\mathbf{G} \varepsilon$ describes the retrieval error.

Same as TES, the a priori information of MOPITT retrievals is from the monthly mean profile of the MOZART$4 \mathrm{CTM}$, without the $10^{\circ}$ latitude $\times 60^{\circ}$ longitude average. We reject MOPITT data with CO column amounts of less than $5 \times 10^{17}$ molec $\mathrm{cm}^{-2}$ and if low clouds are observed. The nighttime data are excluded in the assimilation, due to 
the NIR radiances measured reflected solar radiation. The version 5 data have been evaluated recently against NOAA aircraft measurements (Deeter et al., 2013), which shows a small bias in the low and middle troposphere, but $14 \%$ positive bias at the $200 \mathrm{hPa}$ retrieval level. The new version 6 data significantly reduce the bias in the upper troposphere but magnify the positive bias at the surface level. In this work, we decide to use the new version 6 data, as we focus on the free troposphere (above $800 \mathrm{hPa}$ ), which is not affected by the positive bias in the retrieval at the surface level.

\section{3 $\mathrm{OMI} \mathrm{NO}_{2}$}

The OMI instrument was also launched on NASA's Aura spacecraft. The sensor has a spatial resolution of $13 \mathrm{~km} \times 24 \mathrm{~km}$ (Levelt et al., 2006). OMI provides daily global coverage with measurements of both direct and atmosphere-backscattered sunlight in the ultraviolet-visible range from 270 to $500 \mathrm{~nm}$; $405-465 \mathrm{~nm}$ is used to retrieve tropospheric $\mathrm{NO}_{2}$ columns. In this study, the daily level2 data from the KNMI (Royal Netherlands Meteorological Institute) DOMINO-2 product (Derivation of OMI tropospheric NO2; Boersma et al., 2011) are averaged to obtain monthly mean vertical column densities (VCDs) for subsequent emission inversion. The total error for the retrieved VCDs is about $30 \%$ plus $0.7 \times 10^{15}$ molec $\mathrm{cm}^{-2}$, and the magnitude is larger in winter than in summer (Boersma et al., 2011; Lin and McElroy, 2011). The pixels with cloud radiance fraction exceeding $50 \%$ are removed. In order to have a better analysis of the spatial distribution of VCDs within short distance, we only use data from the 30 pixels around the swath center. The details for the data treatment are described in Lin (2012).

\subsection{GEOS-Chem}

The GEOS-Chem CTM (http://www.geos-chem.org) is driven by assimilated meteorological observation from the NASA Goddard Earth Observing System (GEOS-5) at the Global Modeling and data Assimilation Office. We use version v34 of the GEOS-Chem adjoint, which is based on v802-01 of GEOS-Chem, with relevant updates through v901-01. The standard GEOS-Chem chemistry mechanism includes 43 tracers, which can simulate detailed tropospheric $\mathrm{O}_{3}-\mathrm{NO}_{\mathrm{x}}$-hydrocarbon chemistry, including the radiative and heterogeneous effects of aerosols. The GEOS-5 meteorological fields have 72 vertical levels and the lowest 31 levels are terrain following levels. In order to minimize the amount of memory required to run GEOS-Chem, the model is run with a reduced vertical resolution, in which the levels in the stratosphere are lumped together online.

The native horizontal resolution of GEOS-5 is $0.5^{\circ} \times 0.667^{\circ}$, but it is usually degraded to $4^{\circ} \times 5^{\circ}$ or $2^{\circ} \times 2.5^{\circ}$ in global-scale simulations. A nested simulation can be achieved by running a $0.5^{\circ} \times 0.667^{\circ}$ resolution model within a regional domain using the boundary condition provided from a global, coarse-resolution mode (Wang et al., 2004; Chen et al., 2009). Recently, the adjoint of nested GEOS-Chem was developed by Jiang et al. (2014a). In this work, following Jiang et al. (2014a) and Mao et al. (2014), we run the model with $0.5^{\circ} \times 0.667^{\circ}$ resolution over Asia. The boundary condition is generated with a global-scale $4^{\circ} \times 5^{\circ}$-resolution simulation.

The anthropogenic emission inventories are identical to those used in Jiang et al. (2013). The global anthropogenic emission inventory is EDGAR (Emission Database for Global Atmospheric Research ) version 3.2FT2000 (Olivier et al., 2001), updated by the following regional emission inventories: the INTEX-B Asia emissions inventory for 2006 (Q. Zhang et al., 2009), the Cooperative program for monitoring and evaluation of the long-range transmission of air pollutants in Europe (EMEP) inventory for Europe in 2000 (Vestreng et al., 2002), the US Environmental Protection Agency National Emission Inventory (NEI) for 2005 in North America, the Criteria Air Contaminants (CAC) inventory for Canada, and the Big Bend Regional Aerosol and Visibility Observational (BRAVO) Study Emissions Inventory for Mexico (Kuhns et al., 2003). Biomass burning emissions are from the interannual GFED3 (Global Fire Emissions Database) inventory with $3 \mathrm{~h}$ resolution (van der Werf et al., 2010). The biogenic emissions are from MEGAN 2.0 (Model of Emissions of Gases and Aerosols from Nature version 2; Millet et al., 2008). Figure 1 shows the anthropogenic emission of $\mathrm{NO}_{\mathrm{x}}$ and $\mathrm{CO}$ in Asia in June 2006. There are strong pollutant emissions in the North China Plain. The urban emission centers can also be clearly identified. The annual anthropogenic $\mathrm{NO}_{\mathrm{x}}$ emission over eastern China is $16.5 \mathrm{Tg}$ (2006) and 20.7 Tg (2010), with a $5 \%$ annual growth rate.

\section{Inversion approach}

\subsection{4-DVAR inversion for global CO emission}

In this work, we evaluate the observed interannual variability of $\mathrm{O}_{3}$ and $\mathrm{CO}$ and the GEOS-Chem model simulation for the period of 2006-2010, where the data density of TES measurements is higher relative to subsequent years. As the first year of this 5-year period, the relative contributions of $\mathrm{O}_{3}$ precursors to free troposphere $\mathrm{O}_{3}$ in 2006 will be studied in detail. The 2006 global CO emissions are optimized with a 4-DVAR (four-dimensional variational) method. The inverse method minimizes the cost function $J(\boldsymbol{x})$ to provide an optimal estimate of the $\mathrm{CO}$ sources,

$$
\begin{aligned}
& J(x)=(F(x)-y)^{T} \mathbf{S}_{\Sigma}^{-1}(F(x)-y)+\left(x-x_{\mathrm{a}}\right)^{T} \\
& \mathbf{S}_{\mathrm{a}}^{-1}\left(\boldsymbol{x}-\boldsymbol{x}_{\mathrm{a}}\right),
\end{aligned}
$$

where $\boldsymbol{x}$ is the state vector of emissions, $\boldsymbol{x}_{\mathrm{a}}$ is the a priori estimate, $\boldsymbol{y}$ is a vector of observed concentrations, and $F(\boldsymbol{x})$ 
is the forward model, which represents the transport of the $\mathrm{CO}$ emissions in the GEOS-Chem model and accounts for the vertical smoothing of the MOPITT retrieval. $\mathbf{S}_{\Sigma}$ and $\mathbf{S}_{\mathrm{a}}$ are the observational and a priori error covariance matrices, respectively. The first term of the cost function represents the mismatch between the simulated and observed concentrations. The second term represents the departure of the estimate from the a priori.

The cost function in Eq. (3) is minimized by reducing the gradient, $\partial J / \partial x$, using the adjoint of GEOS-Chem model in a 4-DVAR approach (Henze et al., 2007), which has been previously used for assimilation of $\mathrm{CO}$ and $\mathrm{O}_{3}$ (Kopacz et al., 2010; Singh et al., 2011; Parrington et al., 2012; Jiang et al., 2014b). Similar to Jiang et al. (2013, 2014b), we produce improved initial conditions by assimilating MOPITT version 6 data, using the sequential sub-optimal Kalman filter (Parrington et al., 2008), from 1 January 2006 to 1 January 2007. The optimized initial conditions are archived at the beginning of each month. Consequently, the initial conditions for the model simulation are independent from the inverse analyses.

\subsection{Regression-based inversion for China $\mathrm{NO}_{\mathrm{x}}$ emissions}

The 2006 Chinese $\mathrm{NO}_{\mathrm{x}}$ emissions are optimized with a regression-based multistep method exploiting the distinctive seasonality of different sources (Lin, 2012). Neglecting horizontal transport and assuming a linear relationship between the total VCD of $\mathrm{NO}_{2}$ and VCDs from individual sources, the predicted $\operatorname{VCD}\left(\Omega_{\mathrm{p}}\right)$ for a given grid can be expressed as the sum of individual emission sources, multiplied by certain scaling factors:

$\Omega_{\mathrm{p}}=k_{\mathrm{a}} \Omega_{\mathrm{a}}+k_{\mathrm{l}} \Omega_{1}+k_{\mathrm{s}} \Omega_{\mathrm{s}}+k_{\mathrm{b}} \Omega_{\mathrm{b}}$.

The subscripts "a", "l", "s", and "b" indicate anthropogenic, lightning, soil and biomass burning sources of $\mathrm{NO}_{\mathrm{x}}$, respectively. The updated emission estimates can be obtained by reducing the sum of $\left[\left(\Omega_{\mathrm{r}}-\Omega_{\mathrm{p}}\right) / \sigma\right]^{2}$ across the 12 months; here $\Omega_{\mathrm{r}}$ is the retrieved VCD and $\sigma$ is the standard deviation. To better represent the resolution-dependent $\mathrm{NO}_{\mathrm{x}}$ chemistry (Valin et al., 2011), the inversion was conducted with the highest resolution of GEOS-Chem. The seasonality-based inversion method also reduced the influence of potential biases in $\mathrm{OMI} \mathrm{NO}_{2}$ data (Lin et al., 2014b), particularly in winter. The details for the inversion process were described in Lin (2012).

\section{Results and discussion}

\subsection{Evaluation of the model simulation and top-down estimates of $\mathrm{O}_{3}$ precursors}

In this work, we are interested in the domain of eastern China, as shown in Fig. 1, because it is the largest pollu- tant emission contributor in eastern Asia and the adjacent domain where outflow of Asian pollution is significant. Figure 2 shows the monthly regional mean $\mathrm{O}_{3}$ and $\mathrm{CO}$ concentration at the free troposphere $(681-383 \mathrm{hPa})$ for June, July and August for the period 2006-2010, using the GEOSChem model driven with a priori emission inventories. The modeled $\mathrm{O}_{3}$ concentrations are generally within $10 \%$ of the TES data after accounting for the approximately $7 \mathrm{ppb}$ bias in the TES $\mathrm{O}_{3}$ measurements (e.g., Worden et al., 2007; Verstraeten et al., 2013). However, the modeled CO is biased low, which is consistent with previous studies (Shindell et al., 2006; Kopacz et al., 2010; Naik et al., 2013). This low bias could be associated with a positive bias in $\mathrm{OH}$, as indicated by Jiang et al. (2014b). The bias in CO can be reduced by integrating the coarse-resolution global and fine-resolution nested simulations in a two-way coupled manner, such that results from the nested model can be used to improve the global model (within the nested domain) and ultimately affect its lateral boundary conditions (via the global transport of CO and other species) (Yan et al., 2014). Another possible reason for the CO bias is that the TES CO data are biased towards polluted air parcels because of its relatively low sensitivity whereas the model captures background values as discussed in Pechony et al. (2013). Although the model is biased low, the interannual variabilities and trends of $\mathrm{O}_{3}$ and $\mathrm{CO}$ are well correlated between the model and TES, indicating that changes in the modeled emissions, chemical production of ozone, and meteorology are well described (e.g., Zhang et al., 2006; Kim et al., 2013).

$\mathrm{O}_{3}-\mathrm{CO}$ correlations can be used to constrain $\mathrm{O}_{3}$ sources and transport (e.g., Zhang et al., 2006). Positive correlations usually indicate that a region has experienced photochemical $\mathrm{O}_{3}$ production, whereas negative correlations may result from $\mathrm{O}_{3}$ chemical loss or influence of stratospheric air. For example, Zhang et al. (2006) demonstrated that TES data can be used to examine global distribution of $\mathrm{O}_{3}-\mathrm{CO}$ correlations. Voulgarakis et al. (2011) found significant positive correlations in the northern Pacific during the summer of 2005-2008. Kim et al. (2013) used OMI O 3 and AIRS (Atmospheric Infrared Sounder) CO to show that the GEOSChem model is able to reproduce the observed $\mathrm{O}_{3}-\mathrm{CO}$ correlations and slopes in the western Pacific, but failed in some tropical regions due to model transport error associated with deep convection.

Table 1 shows the monthly regional mean $\mathrm{O}_{3}$ and $\mathrm{CO}$ correlation and slope values for the free troposphere (825$383 \mathrm{hPa}$ ) for June, July and August 2006-2010; the model is driven by a priori emissions. The uncertainty in the $\mathrm{O}_{3}$ and $\mathrm{CO}$ concentrations are due to random errors in the TES $\mathrm{O}_{3}$ and $\mathrm{CO}$ observations and natural variability (Zhang et al., 2006). For this reason, we also show the mean value over the analysis time period. The correlation and slope values of TES and GEOS-Chem are generally consistent for both domains. The positive correlation coefficients imply influence of photochemical $\mathrm{O}_{3}$ production but also transport of nearby $\mathrm{CO}$ 

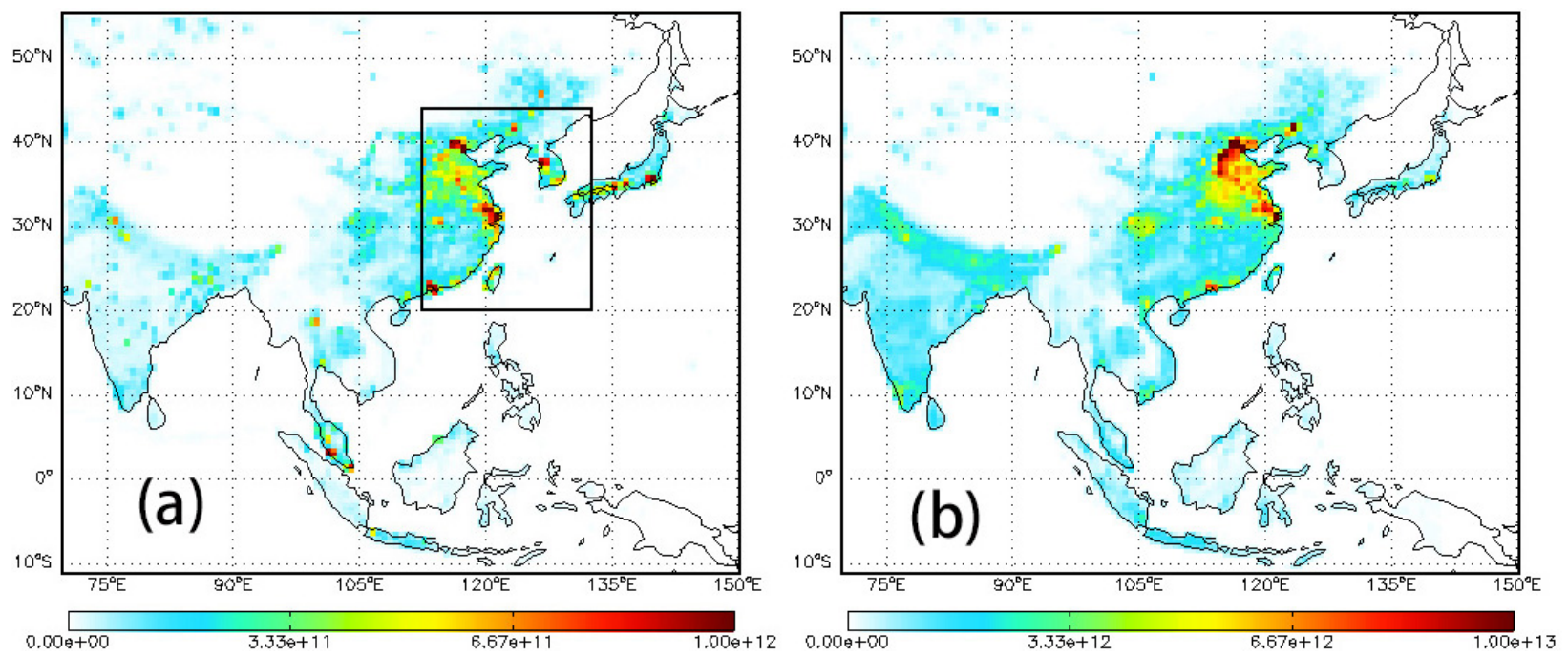

Figure 1. Anthropogenic emission of (a) $\mathrm{NO}_{\mathrm{x}}$ and (b) $\mathrm{CO}$ in June 2006 as used in GEOS-Chem. The unit is in molecules per square centimeter per second (molec $\mathrm{cm}^{-2} \mathrm{~s}^{-1}$ ). The black box defines the domains studied in this work. The "eastern China" domain includes the grids of Chinese mainland within the black box. The "China outflow region" are grids within the black box, excluding the Chinese mainland.
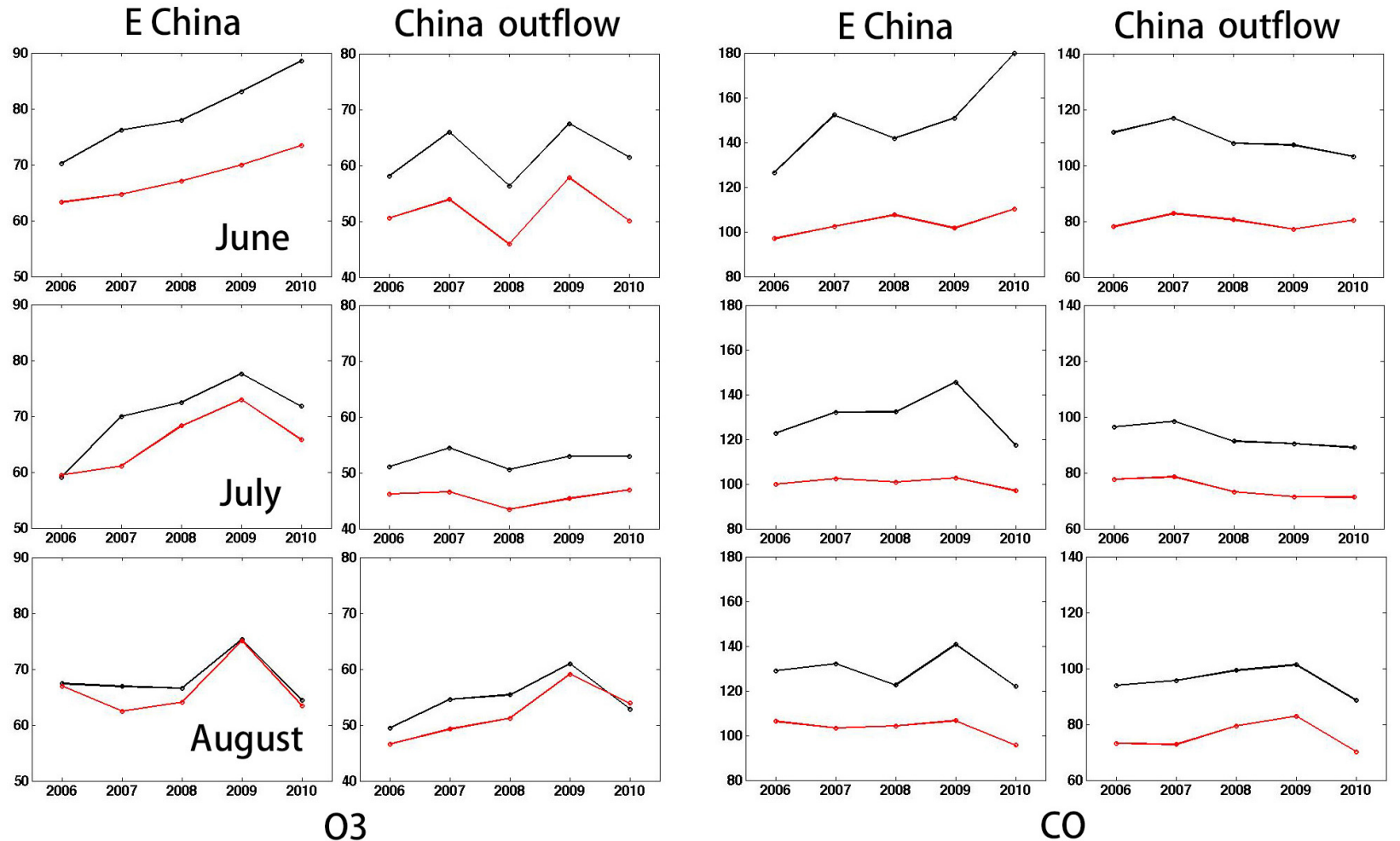

Figure 2. Monthly regional mean $\mathrm{O}_{3}$ and $\mathrm{CO}$ concentration at free troposphere (681-383 hPa) in June, July and August 2006-2010. The red line is the GEOS-Chem model simulation with a priori emission inventories and the black line represents the TES measurements. The model results are smoothed with the TES averaging kernels. The TES ozone data are biased high by 7 ppbv.

emissions into pollution plumes (e.g., Worden et al., 2013) As in previous studies (Zhang et al., 2006; Voulgarakis et al., 2011; Kim et al., 2013), there are small differences between the simulation and observation. A possible reason for these discrepancies, particularly over the ocean, is the model transport error because transport of "clean" air from the Pacific can have substantially different chemical characteristics to Asian air. 
Table 1. Monthly regional mean $\mathrm{O}_{3}$ and $\mathrm{CO}$ correlation and slope for the free troposphere (825-383 hPa) for June, July and August 20062010 for both TES and model (in parentheses). The model values are sampled at the TES measurement time and location and smoothed with the TES averaging kernels. The calculation of slope and correlation is based on individual measurements within a month. The numbers of measurements used to compute the correlations are shown in the Supplement. The far-right column is the mean value of 15 months.

\begin{tabular}{|c|c|c|c|c|c|c|c|c|}
\hline Region & Type & Month & 2006 & 2007 & 2008 & 2009 & 2010 & Mean \\
\hline \multirow[t]{6}{*}{ Eastern China } & \multirow{3}{*}{$\mathrm{dO}_{3} / \mathrm{dCO}$} & Jun & $0.36(0.25)$ & $0.17(-0.06)$ & $0.19(0.14)$ & $0.14(0.02)$ & $0.18(0.29)$ & \multirow{3}{*}{$0.22(0.25)$} \\
\hline & & Jul & $0.08(0.38)$ & $0.29(0.36)$ & $0.23(0.34)$ & $0.15(0.44)$ & $0.38(0.19)$ & \\
\hline & & Aug & $0.20(0.27)$ & $0.22(0.26)$ & $0.32(0.20)$ & $0.15(0.18)$ & $0.29(0.47)$ & \\
\hline & \multirow{3}{*}{$R$} & Jun & $0.66(0.39)$ & $0.47(-0.11)$ & $0.45(0.30)$ & $0.51(0.10)$ & $0.70(0.52)$ & \multirow{3}{*}{$0.50(0.37)$} \\
\hline & & Jul & $0.23(0.61)$ & $0.66(0.57)$ & $0.49(0.38)$ & $0.50(0.57)$ & $0.53(0.24)$ & \\
\hline & & Aug & $0.33(0.38)$ & $0.52(0.43)$ & $0.54(0.28)$ & $0.39(0.22)$ & $0.56(0.64)$ & \\
\hline \multirow{6}{*}{ China outflow } & \multirow{3}{*}{$\mathrm{dO}_{3} / \mathrm{dCO}$} & Jun & $0.32(0.60)$ & $0.49(0.43)$ & $0.52(0.62)$ & $0.59(0.66)$ & $0.64(0.76)$ & \multirow{3}{*}{$0.55(0.70)$} \\
\hline & & Jul & $0.56(0.59)$ & $0.50(0.48)$ & $0.65(0.83)$ & $0.63(1.05)$ & $0.75(1.13)$ & \\
\hline & & Aug & $0.55(0.85)$ & $0.32(0.49)$ & $0.51(0.61)$ & $0.53(0.51)$ & $0.67(0.89)$ & \\
\hline & \multirow{3}{*}{$R$} & Jun & $0.69(0.57)$ & $0.71(0.41)$ & $0.76(0.62)$ & $0.68(0.35)$ & $0.73(0.55)$ & \multirow{3}{*}{$0.67(0.57)$} \\
\hline & & Jul & $0.73(0.57)$ & $0.66(0.47)$ & $0.66(0.69)$ & $0.59(0.70)$ & $0.73(0.78)$ & \\
\hline & & Aug & $0.68(0.71)$ & $0.55(0.46)$ & $0.63(0.60)$ & $0.58(0.39)$ & $0.74(0.75)$ & \\
\hline
\end{tabular}

The consistency between the model and TES in the interannual variations, correlation coefficients and slopes implies that the spatiotemporal distribution of the $\mathrm{CO}$ emissions and oxidative chemical processes are consistent. As described in Sect. 3, the 2006 global CO emissions are constrained with MOPITT data; the 2006 Chinese $\mathrm{NO}_{\mathrm{x}}$ emission are constrained with OMI data. As shown in Fig. 3, Chinese posterior anthropogenic $\mathrm{NO}_{\mathrm{x}}$ emissions in June 2006 increased by $14 \%$ over the a priori emissions, from 1.86 to $2.11 \mathrm{Tg}$. Smaller adjustments are obtained for winter. In June 2006, the Chinese anthropogenic CO emissions increased from 17.09 to $18.93 \mathrm{Tg}$, with a mean scaling factor of 1.11 . In December 2005, the Chinese posterior anthropogenic CO emission increased over the prior from 14.95 to $19.78 \mathrm{Tg}$. However, as indicated by Jiang et al. (2014b), a potential bias in $\mathrm{OH}$ fields could have a significant influence on the inferred $\mathrm{CO}$ emission estimates. By using the $\mathrm{OH}$ fields from a different GEOS-Chem version, they found that a posteriori CO emissions over eastern Asia in June-August 2004 are reduced by $28 \%$ for the different $\mathrm{OH}$ fields. This large potential error in the $\mathrm{CO}$ emissions do not strongly affect our conclusions because the modeled $\mathrm{CO}$ concentrations, based on the model $\mathrm{OH}$ distributions and $\mathrm{CO}$ emissions, are consistent with the MOPITT data.

The monthly regional mean $\mathrm{O}_{3}$ and $\mathrm{CO}$ concentrations in the period of December 2005-November 2006 are shown in Fig. 4. In order to remove the influence of the initial conditions, the updated simulation is obtained by running the model from 1 September 2005, with updated inventories of $\mathrm{NO}_{\mathrm{x}}$ and $\mathrm{CO}$. Both the model and data show increases of $\mathrm{O}_{3}$ concentration from winter to spring, due to enhancement of photochemical production, and a substantial decrease in June-August, due to the effect of the East Asian monsoon (Yang et al., 2014). The CO concentration peaks in March, which is consistent with Shindell et al. (2006). The boreal spring $\mathrm{CO}$ maximum is associated with the accumulation of $\mathrm{CO}$ emissions in winter, while CO lifetime is longer (Duncan et al., 2007). The updated inventories significantly reduced the bias on the $\mathrm{CO}$ simulation. However, these changes in the $\mathrm{NO}_{\mathrm{x}}$ and $\mathrm{CO}$ emissions do not significantly change free tropospheric ozone.

\subsection{Dependency of $\mathrm{O}_{3}$ on anthropogenic and natural $\mathrm{NO}_{\mathrm{x}}, \mathrm{CO}$ and VOCs}

In this section, we will use the adjoint of the GEOS-Chem model (Henze et al., 2007) to quantify source contributions $\left(\mathrm{NO}_{\mathrm{x}}, \mathrm{CO}, \mathrm{VOC}\right)$ to free tropospheric $\mathrm{O}_{3}$ pollution over eastern China and the China outflow region. The updated $\mathrm{NO}_{\mathrm{x}}$ and $\mathrm{CO}$ emission inventories are intended to improve the simulation. We are interested in these two domains as they have significant influence on the long-range pollution transport (e.g., L. Zhang et al., 2009). Similar to previous studies (L. Zhang et al., 2009; Bowman and Henze, 2012; Lapina et al., 2014), the analysis is based on a sensitivity calculation from an adjoint model. In this work, both transport and chemistry components are run backwards and thus provide a more computationally efficient method for a receptororiented problem than the traditional approach by perturbing emissions.

Figure 5 shows the contributions of anthropogenic $\mathrm{NO}_{\mathrm{x}}$, lightning $\mathrm{NO}_{\mathrm{x}}$, anthropogenic $\mathrm{CO}$ and biogenic isoprene on free tropospheric (819-396 hPa) $\mathrm{O}_{3}$ over eastern China. The value can be explained as the percentage change of regional mean $\mathrm{O}_{3}$ due to a fractional change in emissions in a particular grid. For example, assuming an unchanged chemical environment, one particular grid with contribution $0.02 \%$ implies mean free tropospheric $\mathrm{O}_{3}$ over eastern China will 

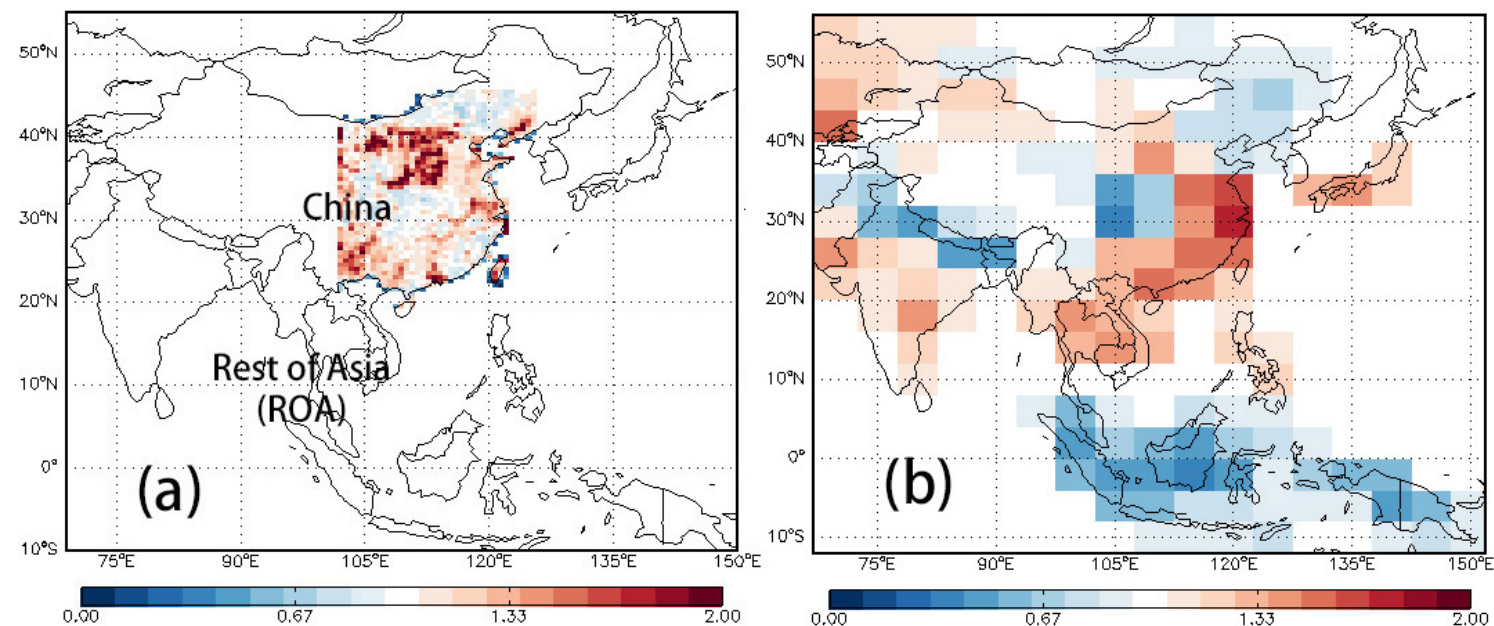

Figure 3. (a) Scaling factors of anthropogenic $\mathrm{NO}_{\mathrm{x}}$ for June 2006. (b) Scaling factor of total $\mathrm{CO}$ emission (combustion + oxidation from biogenic VOCs) for June 2006.

03
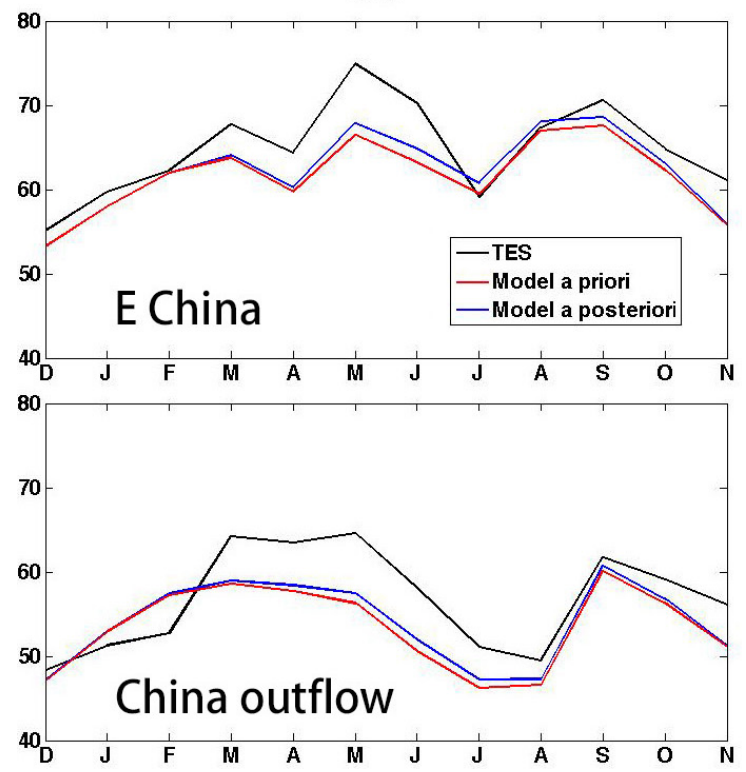

$\mathrm{CO}$
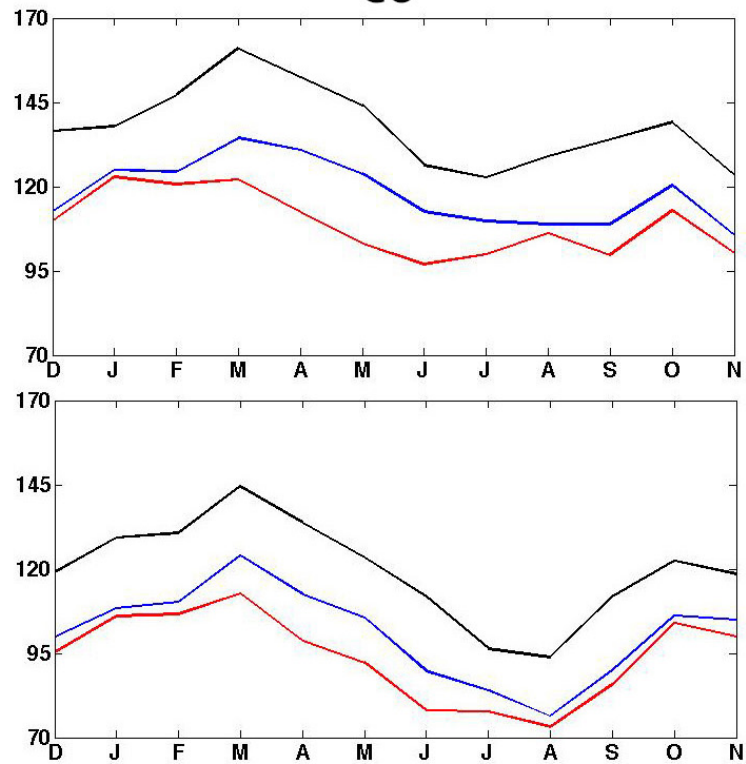

Figure 4. Monthly regional mean $\mathrm{O}_{3}$ and $\mathrm{CO}$ concentration at free troposphere (681-383 hPa) in the period of December 2005-November 2006. The red line is GEOS-Chem model simulation with a priori emission inventories. The blue line is model simulation with updated $\mathrm{NO}_{\mathrm{X}}$ and $\mathrm{CO}$ emission inventories. The black line represents TES measurements. The model results are smoothed with the TES averaging kernels. The positive bias in the TES $\mathrm{O}_{3}$ data is larger in summer and smaller in winter.

be increased by $0.02 \%$, if the $\mathrm{NO}_{\mathrm{x}}$ emission in this gird is increased by $100 \%$. The result shows that anthropogenic $\mathrm{NO}_{\mathrm{x}}$ contributes significantly to the $\mathrm{O}_{3}$ distribution in this region. Although the influence of lightning $\mathrm{NO}_{\mathrm{x}}$ is weaker, the larger geographical distribution of lightning $\mathrm{NO}_{\mathrm{x}}$ makes it an important source. The contribution of anthropogenic $\mathrm{CO}$ is mainly from China, whereas southeastern Asia is the major contributor of biogenic isoprene with a negative sensitivity. Assuming anthropogenic CO is a proxy of anthropogenic hydrocarbons and biogenic isoprene is a proxy of biogenic hydrocarbons, these sensitivity calculations indicate that China is a major source of anthropogenic hydrocarbons while southeastern Asia is the major source of biogenic hydrocarbons. As shown in Fig. 1, the North China Plain has strong $\mathrm{NO}_{\mathrm{x}}$ emissions, but their effect on $\mathrm{O}_{3}$ is not significant. However, eastern China free tropospheric $\mathrm{O}_{3}$ is more directly sensitive to $\mathrm{CO}$ emissions from the North China Plain. The contribution of $\mathrm{CO}$ to ozone production (third set of panels in Fig. 5) is similar to the CO emissions distribution. Discrepancies exist between the spatial distribution of 
the sensitivity of ozone to $\mathrm{NO}_{\mathrm{x}}$ and $\mathrm{CO}$. For example, the sensitivity of ozone to $\mathrm{NO}_{\mathrm{x}}$ in the Beijing area is relatively small because there is too much $\mathrm{NO}_{\mathrm{x}}$, thus limiting ozone production. Martin et al. (2004) showed that an increase of $\mathrm{NO}_{\mathrm{x}}$ emission over northeastern China in summer will decrease surface $\mathrm{O}_{3}$ concentration, which is opposite to the positive sensitivity in this work. This difference could be associated with the larger concentrations of VOC levels (e.g., Zhang et al., 2014) and because the sensitivities shown in Fig. 5 depend on both surface ozone production and ozone production in the free troposphere, which is more $\mathrm{NO}_{\mathrm{x}} \mathrm{lim}$ ited.

It should be reminded that the sensitivity of ozone to biogenic isoprene is highly dependent on the isoprene chemistry scheme, as indicated by Mao et al. (2013). They demonstrated that the sensitivity of surface $\mathrm{O}_{3}$ concentration over the southeastern United States on isoprene could change sign, from negative to positive, with two different isoprene schemes. However, as shown in Fig. 5 the influence of the isoprene scheme on free tropospheric $\mathrm{O}_{3}$ is small relative to that from $\mathrm{NO}_{\mathrm{x}}$ so that we do not expect errors in the isoprene scheme to significantly alter our conclusions. These results are consistent with Mao et al. (2013) as they show that a change in sign in the sensitivity of ozone to isoprene only affected their surface ozone concentrations by 2 ppb or less and therefore had an even smaller effect on free tropospheric ozone concentrations.

The contributions to the free tropospheric ozone in the the China outflow region are shown in Fig. 6. The $\mathrm{O}_{3}$ distribution is more sensitive to the anthropogenic $\mathrm{NO}_{\mathrm{x}}$ emissions from the coast rather than from the inland continent. The sensitivity hot spots clearly show a northeastward movement as the season progresses, from southeastern China (June) to Korea and Japan (August), reflecting the influence of the East Asian monsoon.

To understand the seasonal variation of $\mathrm{O}_{3}$ production efficiency, we calculated the global-scale sensitivities of anthropogenic and lightning $\mathrm{NO}_{\mathrm{x}}$ during December 2005November 2006 with $4^{\circ} \times 5^{\circ}$ resolution. The values of sensitivities, as shown in Fig. 7, are significantly larger than those in Figs. 5 and 6, due to the change of grid size and smaller effect from initial condition. The sensitivity of $\mathrm{O}_{3}$ to anthropogenic $\mathrm{NO}_{\mathrm{x}}$ has a marked seasonal variation, increasing in the Northern Hemisphere from winter to the summer. Kondo et al. (2008) found the slope of eastern Asia $\mathrm{O}_{3}$ formation to $\mathrm{NO}_{\mathrm{x}}$ is proportional to $\mathrm{HO}_{2}$ and thus increases from winter to spring. Increased solar radiation is another reason for the high $\mathrm{O}_{3}$ production rate in the summer. Figure 7 also highlights the effect of anthropogenic $\mathrm{NO}_{\mathrm{x}}$ from southwestern China, showing a significant effect on free troposphere $\mathrm{O}_{3}$ over eastern China, particularly in SeptemberNovember. Similar to anthropogenic $\mathrm{NO}_{\mathrm{x}}$, the contribution of lightning $\mathrm{NO}_{\mathrm{x}}$ is maximum in the Northern Hemisphere summer, partly associated with the East Asian monsoon. The sensitivities of $\mathrm{O}_{3}$ over eastern China and the China outflow region have similar distributions, although the China outflow $\mathrm{O}_{3}$ is more sensitive to coastal emissions.

Table 2 shows the regional, total contributions of anthropogenic and lightning $\mathrm{NO}_{\mathrm{x}}$, calculated by summing the sensitivities shown in Fig. 7. Assuming an unchanged chemical environment, it can be explained as the percentage change of regional mean $\mathrm{O}_{3}$ due to a $100 \%$ change in $\mathrm{NO}_{\mathrm{x}}$ emissions. For example, a $100 \%$ increase of Chinese anthropogenic $\mathrm{NO}_{\mathrm{x}}$ emissions in June-August 2006 will result in $10.2 \%$ increase of tropospheric mean $\mathrm{O}_{3}$ over eastern China. Of course, the result of an actual $100 \%$ change of $\mathrm{NO}_{\mathrm{x}}$ will be different because of nonlinear chemistry. Furthermore, this sensitivity depends on the modeled transport and the robustness of the chemical production of ozone. For example, if the production of ozone is too "fast" then the sensitivity of free tropospheric ozone to surface emissions is too small as too much ozone is produced in the boundary layer (where lossmechanisms dominate) versus the free troposphere. To evaluate the sensitivities further, we enhanced Chinese anthropogenic $\mathrm{NO}_{\mathrm{x}}$ emissions by $10 \%$ uniformly as a perturbation. Using the initial conditions provided from the standard simulation, the 3-month perturbation simulations are started on 1 December 2005, 1 March 2006, 1 June 2006 and 1 September 2006, individually. The relative difference of regional mean $\mathrm{O}_{3}$ between the perturbation and standard simulations is then multiplied by 10. As shown in Table 2, the results of the two methods are highly consistent, which demonstrates our sensitivity analysis works well. Similar to Wild et al. (2012), the consistency also confirms that $10 \% \mathrm{NO}_{\mathrm{x}}$ perturbation gives a linear $\mathrm{O}_{3}$ response over eastern Asia. Considering the high computation efficiency, adjoint sensitivity analysis is thus a good alternative to the traditional perturbation method.

As shown in Table 2, the effect of increased Chinese anthropogenic $\mathrm{NO}_{\mathrm{x}}$ on free tropospheric $\mathrm{O}_{3}$ is limited. Assuming an unchanged chemical environment, a $100 \%$ increase of Chinese anthropogenic $\mathrm{NO}_{\mathrm{x}}$, during a 3-month period, will only result in a $2.4 \%$ increase of free tropospheric $\mathrm{O}_{3}$ in the winter and $10.2 \%$ in the summer, associated with the chemical environment of China, which is is more inclined to be VOC limited. Because of the long $\mathrm{O}_{3}$ lifetime in the free troposphere, $\mathrm{O}_{3}$ from initial conditions has a substantial influence on the distribution of ozone. A 15-month continuous perturbation simulation, started on 1 September 2005, will enhance the effect of Chinese anthropogenic $\mathrm{NO}_{\mathrm{x}}$ to $3.0 \%$ in winter and $10.5 \%$ in summer.

Because of the rapid growth of pollutant emissions, the transpacific transport of Asian pollutants to North America has attracted significant attention (Zhang et al., 2008; L. Zhang et al., 2009; Walker et al., 2010; Bertram et al., 2013; Lin et al., 2008, 2014a). The major transport mechanisms include the northeastward export of Asian pollution to about $50^{\circ} \mathrm{N}$, and then the transport across the Pacific in midlatitude westerly winds (Liang et al., 2004, 2005). Over eastern China, the effect of anthropogenic $\mathrm{NO}_{\mathrm{x}}$ emissions from the rest of Asia (ROA) on free tropospheric $\mathrm{O}_{3}$ is that 

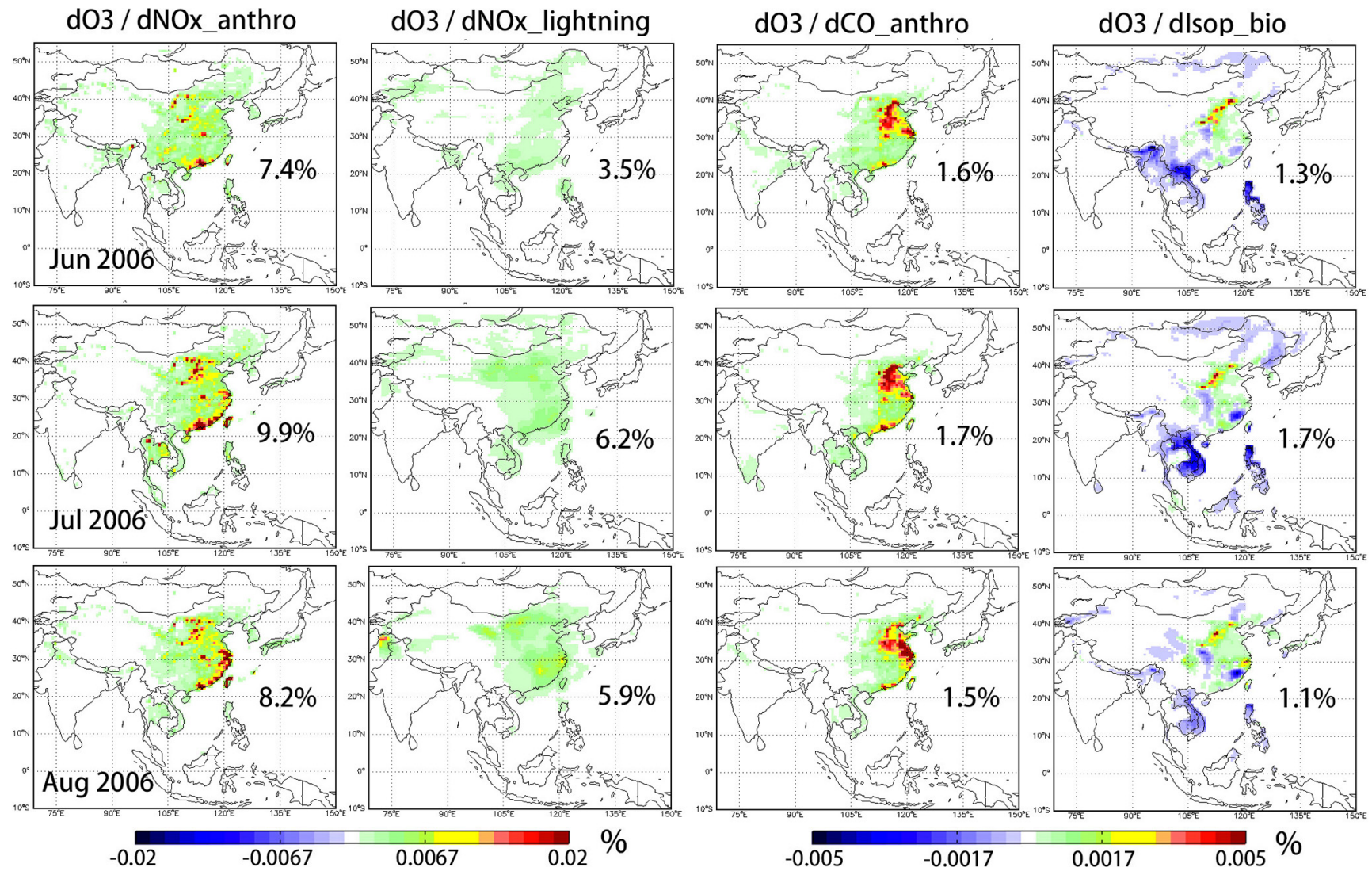

Figure 5. Contributions of anthropogenic $\mathrm{NO}_{\mathrm{x}}$, lightning $\mathrm{NO}_{\mathrm{x}}$, anthropogenic $\mathrm{CO}$, biogenic isoprene on free tropospheric (819-396hPa) $\mathrm{O}_{3}$ over eastern China derived from the adjoint of GEOS-Chem in June, July and August 2006. The contributions can be explained as the percentage of change of regional mean ozone due to a fractional change in the emissions in a particular grid assuming an unchanged chemical environment. The numbers are the total of the absolute value of precursor contributions for the whole domain shown in the figures.

Table 2. Regional, total contributions of anthropogenic and lightning $\mathrm{NO}_{\mathrm{x}}$ on free tropospheric $(819-396 \mathrm{hPa}) \mathrm{O}_{3}$ over eastern China and the China outflow region. The value can be explained as the percentage change of regional mean $\mathrm{O}_{3}$ (eastern China, China outflow) due to $100 \%$ increase of $\mathrm{NO}_{\mathrm{x}}$ in a particular region (China and ROA). The regions of China and the ROA are defined in Fig. 3. The perturbation values $(\mathrm{Pt})$ are the relative difference between standard and perturbation simulations.

\begin{tabular}{llrrrr|rrrr}
\hline \multirow{2}{*}{ Type } & \multicolumn{4}{c}{ Eastern China } & \multicolumn{4}{c}{ China outflow } \\
\cline { 3 - 9 } & & DJF & MAM & JJA & SON & DJF & MAM & JJA & SON \\
\hline \multirow{3}{*}{ NO $_{x}$ anthro } & China & $2,4 \%$ & $5,2 \%$ & $10,2 \%$ & $7,0 \%$ & $2,6 \%$ & $5,5 \%$ & $8,6 \%$ & $5,8 \%$ \\
& China (Pt) & $2,6 \%$ & $5,3 \%$ & $10,2 \%$ & $6,8 \%$ & $2,9 \%$ & $5,8 \%$ & $8,5 \%$ & $5,7 \%$ \\
& ROA & $1,7 \%$ & $2,0 \%$ & $2,2 \%$ & $2,0 \%$ & $2,2 \%$ & $2,4 \%$ & $3,4 \%$ & $2,9 \%$ \\
\hline \multirow{2}{*}{ NO $_{x}$ lightning } & China & $0,2 \%$ & $1,6 \%$ & $6,1 \%$ & $1,4 \%$ & $0,3 \%$ & $2,3 \%$ & $6,3 \%$ & $1,7 \%$ \\
& ROA & $0,8 \%$ & $2,2 \%$ & $2,6 \%$ & $1,9 \%$ & $1,2 \%$ & $3,1 \%$ & $3,9 \%$ & $2,8 \%$ \\
\hline
\end{tabular}

of about $50 \%$ of the Chinese local emissions in winter and spring, whereas the Chinese local emissions dominate in the summer and fall. Our results show that the influence of the $\mathrm{ROA}$ on $\mathrm{O}_{3}$ pollution export is significant because the influence of the ROA is comparable with Chinese emissions in winter and about $50 \%$ of the Chinese emissions in other seasons for the outflow region. The contribution of lightning $\mathrm{NO}_{\mathrm{x}}$ over China is generally small relative to anthropogenic emissions except during the summer (Table 2). The effect of the ROA lightning $\mathrm{NO}_{\mathrm{x}}$ is similar to the Chinese contribution but slightly larger. 

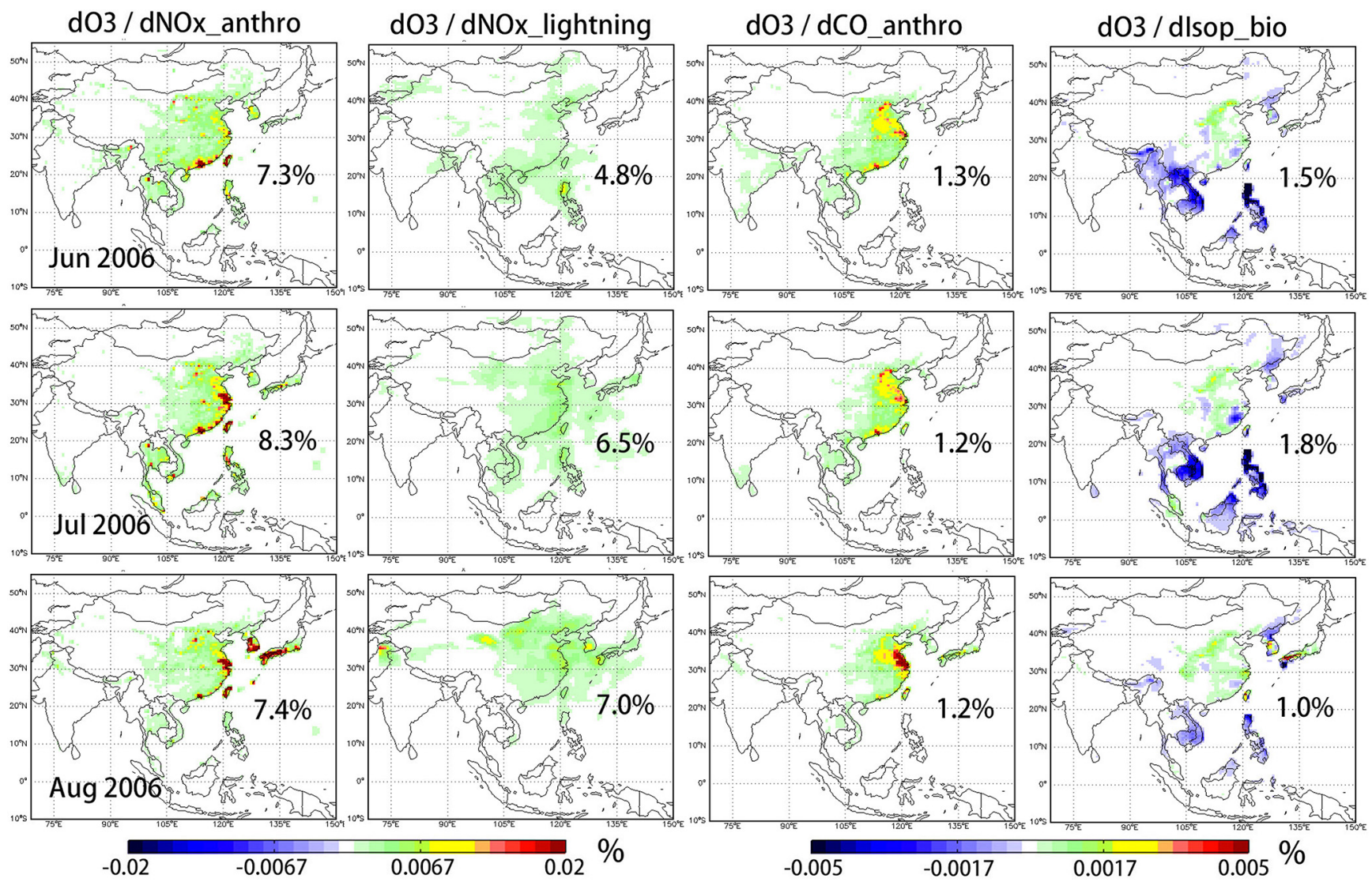

Figure 6. Contributions of anthropogenic $\mathrm{NO}_{\mathrm{x}}$, lightning $\mathrm{NO}_{\mathrm{x}}$, anthropogenic $\mathrm{CO}$, and biogenic isoprene on free tropospheric (819-396 hPa) $\mathrm{O}_{3}$ over China outflow region derived from the adjoint of GEOS-Chem in June, July and August 2006.

\section{Summary}

We quantified Asian $\mathrm{O}_{3}$ and the contributions of its precursors, during the period December 2005-November 2006, using the GEOS-Chem model and $\mathrm{O}_{3}$ precursor observations of $\mathrm{NO}_{2}$ from OMI and CO from MOPITT. The 2006 global $\mathrm{CO}$ emissions are constrained with a 4-DVAR method, using MOPITT CO (version 6) measurements. In June 2006, the inversion increases the China anthropogenic $\mathrm{CO}$ emission by $11 \%$. The 2006 China $\mathrm{NO}_{\mathrm{x}}$ emission is constrained with a regression-based multistep approach, using OMI data. In June 2006, the anthropogenic $\mathrm{NO}_{\mathrm{x}}$ emission in China increased by $14 \%$.

The model simulation is evaluated with TES $\mathrm{O}_{3}$ and $\mathrm{CO}$ observations. The modeled concentrations are underestimated for both $\mathrm{O}_{3}$ and $\mathrm{CO}$, but reproduce the $\mathrm{O}_{3}(\mathrm{CO})$ interannual variation. As with previous studies (Zhang et al., 2006; Voulgarakis et al., 2011; Kim et al., 2013), the modeled $\mathrm{O}_{3}-\mathrm{CO}$ correlation and slope are consistent with the data. The updated inventories significantly reduce the bias relative to TES CO measurements, but the improvement on the $\mathrm{O}_{3}$ simulation is not large $(\sim 1-2 \%)$. The good agreement between model $\mathrm{O}_{3}$ and $\mathrm{CO}$ and its correlations with obser- vations from TES demonstrates the reliability of the model simulation, the chemical scheme and the updated CO inventories.

We quantified source contributions $\left(\mathrm{NO}_{\mathrm{x}}, \mathrm{CO}, \mathrm{VOC}\right)$ to free tropospheric $\mathrm{O}_{3}$ pollution over eastern China and the China outflow region with a sensitivity calculation approach. Our results show anthropogenic emissions from China are the major contributor to free tropospheric $\mathrm{O}_{3}$ over eastern Asia and the corresponding outflow region. The anthropogenic emissions from the ROA have an important influence on free tropospheric $\mathrm{O}_{3}$ over this region. The observed seasonal variation in $\mathrm{O}_{3}$ is due to the seasonal change in the $\mathrm{O}_{3}$ production efficiency, related to $\mathrm{HO}_{2}$ and solar radiation. The contributions of lightning $\mathrm{NO}_{x}$ to free tropospheric $\mathrm{O}_{3}$ from China and the ROA are small, except in June-August due to the effect of the East Asian monsoon. Finally, our result shows that China is the major contributor of anthropogenic VOCs, whereas the influence of biogenic VOCs is mainly from southeastern Asia. 

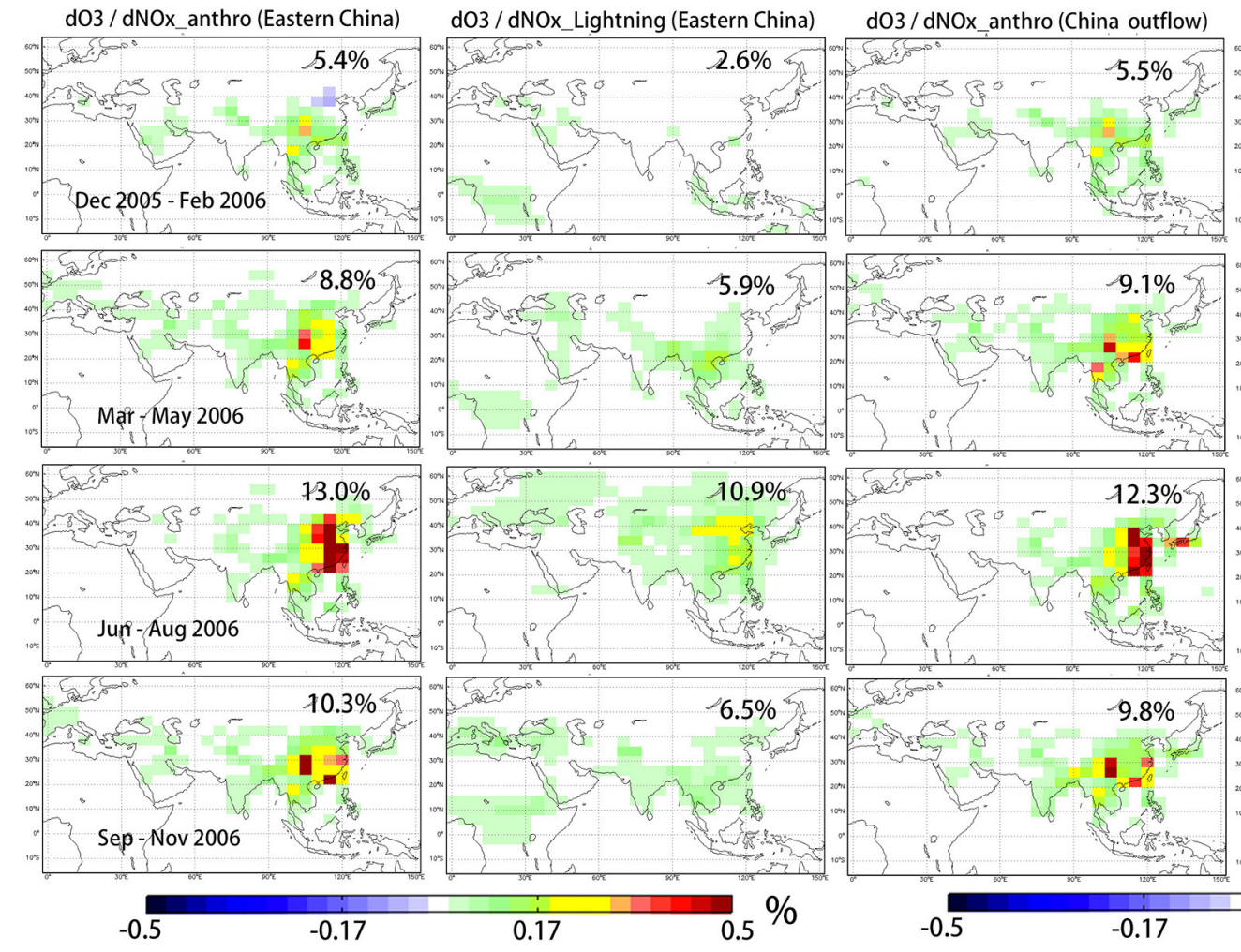

dO3 / dNOx_lightning (China outflow)
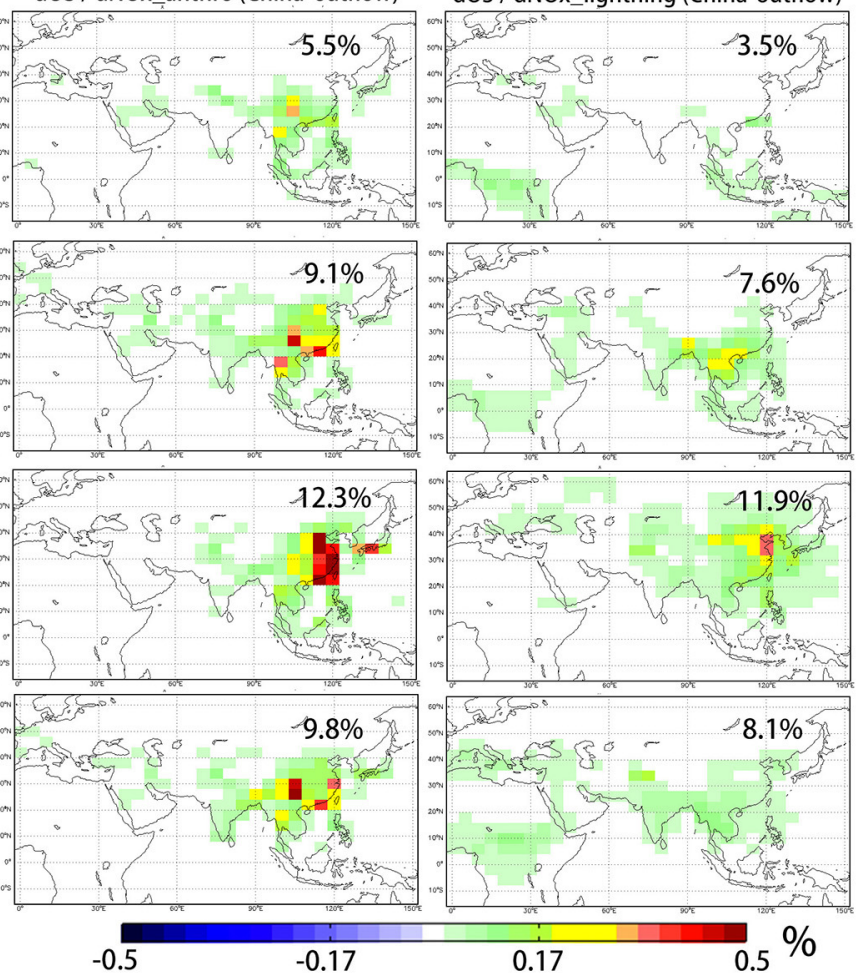

Figure 7. Contributions of anthropogenic $\mathrm{NO}_{\mathrm{x}}$ and lightning $\mathrm{NO}_{\mathrm{x}}$ on free tropospheric (819-396hPa) $\mathrm{O}_{3}$ over eastern China and the China outflow region in December 2005-November 2006.

\section{The Supplement related to this article is available online at doi:10.5194/acp-15-99-2015-supplement.}

Acknowledgements. Part of this research was carried out at the Jet Propulsion Laboratory, California Institute of Technology, under a contract with the National Aeronautics and Space Administration. This Research was supported by the NASA ROSES Aura Science Team NNH10ZDA001N-AURA. Daven K. Henze was funded by NASA ACMAP NNX13AK86G. Willem W. Verstraeten was funded by the Netherlands Organization for Scientific Research, NWO Vidi grant 864.09.001.

Edited by: R. Harley

\section{References}

Beer, R., Glavich, T. A., and Rider, D. M.: Tropospheric emission spectrometer for the Earth Observing System's Aura satellite, Appl. Optics, 40, 2356-2367, 2001.

Bertram, T. H., Perring, A. E., Wooldridge, P. J., Dibb, J., Avery, M. A., and Cohen, R. C.: On the export of reactive nitrogen from Asia: $\mathrm{NO}_{\mathrm{x}}$ partitioning and effects on ozone, Atmos. Chem. Phys., 13, 4617-4630, doi:10.5194/acp-13-4617-2013, 2013.
Boersma, K. F., Eskes, H. J., Dirksen, R. J., van der A, R. J., Veefkind, J. P., Stammes, P., Huijnen, V., Kleipool, Q. L., Sneep, M., Claas, J., Leitão, J., Richter, A., Zhou, Y., and Brunner, D.: An improved tropospheric $\mathrm{NO}_{2}$ column retrieval algorithm for the Ozone Monitoring Instrument, Atmos. Meas. Tech., 4, 19051928, doi:10.5194/amt-4-1905-2011, 2011.

Bowman, K. and Henze, D. K.: Attribution of direct ozone radiative forcing to spatially resolved emissions, Geophys. Res. Lett., 39, L22704, doi:10.1029/2012GL053274, 2012.

Brown-Steiner, B. and Hess, P.: Asian influence on surface ozone in the United States: a comparison of chemistry, seasonality, and transport mechanisms, J. Geophys. Res., 116, D17309, doi:10.1029/2011JD015846, 2011.

Chen, D., Wang, Y., McElroy, M. B., He, K., Yantosca, R. M., and Le Sager, P.: Regional CO pollution and export in China simulated by the high-resolution nested-grid GEOS-Chem model, Atmos. Chem. Phys., 9, 3825-3839, doi:10.5194/acp-9-3825-2009, 2009.

Deeter, M. N., Martiìnez-Alonso, S., Edwards, D. P., Emmons, L. K., Gille, J. C., Worden, H. M., Pittman, J. V., Daube, B. C., and Wofsy, S. C.: Validation of MOPITT Version 5 thermal- infrared, near-infrared, and multispectral carbon monoxide profile retrievals for 2000-2011, J. Geophys. Res.-Atmos., 118, 67106725, 2013.

Duncan, B. N., Logan, J. A. Bey, I., Megretskaia, I. A., Yantosca, R. M., Novelli, P. C., Jones, N. B., and Rinsland, C. P.: Global budget of CO, 1988-1997: Source estimates and val- 
idation with a global model, J. Geophys. Res., 112, D22301, doi:10.1029/2007JD008459, 2007.

Fortems-Cheiney, A., Chevallier, F., Pison, I., Bousquet, P., Szopa, S., Deeter, M. N., and Clerbaux, C.: Ten years of $\mathrm{CO}$ emissions as seen from Measurements of Pollution in the Troposphere (MOPITT), J. Geophys. Res., 116, D05304, doi:10.1029/2010JD014416, 2011.

Fu, T.-M., Jacob, D. J., Palmer, P. I., Chance, K., Wang, Y. X., Barletta, B., Blake, D. R., Stanton, J. C., and Pilling, M. J.: Space-based formaldehyde measurements as constraints on volatile organic compound emissions in east and south Asia and implications for ozone, J. Geophys. Res., 112, D06312, doi:10.1029/2006JD007853, 2007.

Gonzi, S., Feng, L., and Palmer, P. I.: Seasonal cycle of emissions of CO inferred from MOPITT profiles of CO: sensitivity to pyroconvection and profile retrieval assumptions, Geophys. Res. Lett., 38, L08813, doi:10.1029/2011GL046789, 2011.

Henze, D. K., Hakami, A., and Seinfeld, J. H.: Development of the adjoint of GEOS-Chem, Atmos. Chem. Phys., 7, 2413-2433, doi:10.5194/acp-7-2413-2007, 2007.

Jiang, Z., Jones, D. B. A., Worden, H. M., Deeter, M. N., Henze, D. K., Worden, J., Bowman, K. W., Brenninkmeijer, C. A. M., and Schuck, T. J.: Impact of model errors in convective transport on CO source estimates inferred from MOPITT CO retrievals, J. Geophys. Res.-Atmos., 118, 2073-2083, 2013.

Jiang, Z., Jones, D. B. A., Worden, J., Worden, H., Henze, D., and Wang, Y. X.: Regional data assimilation of multi-spectral MOPITT observations of CO over North America, in preparation, 2014a.

Jiang, Z., Jones, D. B. A., Worden, H. M., and Henze, D. K.: Sensitivity of inferred regional CO source estimates to the vertical structure in $\mathrm{CO}$ as observed by MOPITT, Atmos. Chem. Phys. Discuss., 14, 22939-22984, doi:10.5194/acpd-14-229392014, 2014b.

Kim, P. S., Jacob, D. J., Liu, X., Warner, J. X., Yang, K., Chance, K., Thouret, V., and Nedelec, P.: Global ozone-CO correlations from OMI and AIRS: constraints on tropospheric ozone sources, Atmos. Chem. Phys., 13, 9321-9335, doi:10.5194/acp-13-93212013, 2013.

Kondo, J., Hudman, R. C., Nakamura, K., Koike, M., Chen, G., Miyazaki, Y., Takegawa, N., Blake, D. R., Simpson, I. J., Ko, M., Kita, K., and Shirai, T.: Mechanisms that influence the formation of high-ozone regions in the boundary layer downwind of the Asian continent in winter and spring, J. Geophys. Res., 113, D15304, doi:10.1029/2007JD008978, 2008.

Kopacz, M., Jacob, D. J., Fisher, J. A., Logan, J. A., Zhang, L., Megretskaia, I. A., Yantosca, R. M., Singh, K., Henze, D. K., Burrows, J. P., Buchwitz, M., Khlystova, I., McMillan, W. W., Gille, J. C., Edwards, D. P., Eldering, A., Thouret, V., and Nedelec, P.: Global estimates of CO sources with high resolution by adjoint inversion of multiple satellite datasets (MOPITT, AIRS, SCIAMACHY, TES), Atmos. Chem. Phys., 10, 855-876, doi:10.5194/acp-10-855-2010, 2010.

Kuhns, H., Green, M., and Etyemezian, V.: Big Bend Regional Aerosol and Visibility Observational (BRAVO) Study Emissions Inventory, Report prepared for BRAVO Steering Committee, Desert Research Institute, Las Vegas, Nevada, 2003.

Lamsal, L. N., Martin, R. V., Padmanabhan, A., van Donkelaar, A., Zhang, Q., Sioris, C. E., Chance, K., Kurosu,
T. P., and Newchurch, M. J.: Application of satellite observations for timely updates to global anthropogenic $\mathrm{NO}_{\mathrm{x}}$ emission inventories, Geophys. Res. Lett., 38, L05810, doi:10.1029/2010GL046476, 2011.

Lapina, K., Henze, D. K., Milford, J. B., Huang, M., Lin, M., Fiore, A. M., Carmichael, G., Pfister, G. G., and Bowman, K.: Assessment of source contributions to seasonal vegetative exposure to ozone in the U.S., J. Geophys. Res.-Atmos., 119, 324-340, 2014.

Levelt, P. F., van den Oord, G. H. J., Dobber, M. R., Malkki, A., Visser, H., de Vries, J., Stammes, P., Lundell, J. O. V., and Saari, H.: The Ozone Monitoring Instrument, IEEE T. Geosci. Remote, 44, 1093-1101, 2006.

Liang, Q., Jaegle, L., Jaffe, D. A., Weiss-Penzias, P., Heckman, A., and Snow, J. A.: Long- range transport of Asian pollution to the northeast Pacific: seasonal variations and transport pathways of carbon monoxide, J. Geophys. Res., 109, D23S07, doi:10.1029/2003JD004402, 2004.

Liang, Q., Jaegle, L., and Wallace, J. M.: Meteorological indices for Asian outflow and transpacific transport on daily to interannual timescales, J. Geophys. Res., 110, D18308, doi:10.1029/2005JD005788, 2005.

Lin, J.-T.: Satellite constraint for emissions of nitrogen oxides from anthropogenic, lightning and soil sources over East China on a high-resolution grid, Atmos. Chem. Phys., 12, 2881-2898, doi:10.5194/acp-12-2881-2012, 2012.

Lin, J.-T. and McElroy, M. B.: Detection from space of a reduction in anthropogenic emissions of nitrogen oxides during the Chinese economic downturn, Atmos. Chem. Phys., 11, 8171-8188, doi:10.5194/acp-11-8171-2011, 2011.

Lin, J.-T., Wuebbles, D. J., and Liang, X. Z.: Effects of intercontinental transport on surface ozone over the United States: present and future assessment with a global model, Geophys. Res. Lett., 35, L02805, doi:10.1029/2007GL031415, 2008.

Lin, J.-T., Liu, Z., Zhang, Q., Liu, H., Mao, J., and Zhuang, G.: Modeling uncertainties for tropospheric nitrogen dioxide columns affecting satellite-based inverse modeling of nitrogen oxides emissions, Atmos. Chem. Phys., 12, 12255-12275, doi:10.5194/acp-12-12255-2012, 2012.

Lin, J.-T., Pan, D., Davis, S. J., Zhang, Q., He, K., Wang, C., Streets, D. G., Wuebbles, D. J., and Guan, D.: China's international trade and air pollution in the United States, P. Natl. Acad. Sci. USA, 11, 1736-1741, doi:10.1073/pnas.1312860111, 2014a.

Lin, J.-T., Martin, R. V., Boersma, K. F., Sneep, M., Stammes, P., Spurr, R., Wang, P., Van Roozendael, M., Clémer, K., and Irie, H.: Retrieving tropospheric nitrogen dioxide from the Ozone Monitoring Instrument: effects of aerosols, surface reflectance anisotropy, and vertical profile of nitrogen dioxide, Atmos. Chem. Phys., 14, 1441-1461, doi:10.5194/acp-14-1441-2014, 2014b.

Liu, J. and Mauzerall, D. L.: Estimating the average time for intercontinental transport of air pollutants, Geophys. Res. Lett., 32, L11814, doi:10.1029/2005GL022619, 2005.

Luo, M., Rinsland, C., Fisher, B., Sachse, G., Diskin, G., Logan, J., Worden, H., Kulawik, S., Osterman, G., Eldering, A., Herman, R., and Shephard, M.: TES carbon monoxide validation with DACOM aircraft measurements during INTEX-B 2006, J. Geophys. Res., 112, D24S48, doi:10.1029/2007JD008803, 2007.

Mao, J., Paulot, F., Jacob, D. J., Cohen, R. C., Crounse, J. D., Wennberg, P. O., Keller, C. A., Hudman, R. C., Barkley, M. P., 
and Horowitz, L. W.: Ozone and organic nitrates over the eastern United States: sensitivity to isoprene chemistry, J. Geophys. Res.-Atmos., 118, 11256-11268, doi:10.1002/jgrd.50817, 2013.

Mao, Y. H., Li, Q. B., Henze, D. K., Jiang, Z., Jones, D. B. A., Kopacz, M., He, C., Qi, L., Gao, M., Hao, W.-M., and Liou, K.-N.: Variational estimates of black carbon emissions in the western United States, Atmos. Chem. Phys. Discuss., 14, 21865 21916, doi:10.5194/acpd-14-21865-2014, 2014.

Martin, R. V., Fiore, A. M., and Donkelaar, A. Van: Space-based diagnosis of surface ozone sensitivity to anthropogenic emissions, Geophys. Res. Lett., 31, L06120, doi:10.1029/2004GL019416, 2004

Mijling, B., van der A, R. J., and Zhang, Q.: Regional nitrogen oxides emission trends in East Asia observed from space, Atmos. Chem. Phys., 13, 12003-12012, doi:10.5194/acp-1312003-2013, 2013.

Millet, D. B., Jacob, D. J., Boersma, K. F., Fu, T. M., Kurosu, T. P., Chance, K., Heald, C. L., and Guenther, A.: Spatial distribution of isoprene emissions from North America derived from formaldehyde column measurements by the OMI satellite sensor, J. Geophys. Res., 113, D02307, doi:10.1029/2007JD008950, 2008.

Naik, V., Voulgarakis, A., Fiore, A. M., Horowitz, L. W., Lamarque, J.-F., Lin, M., Prather, M. J., Young, P. J., Bergmann, D., Cameron-Smith, P. J., Cionni, I., Collins, W. J., Dalsøren, S. B., Doherty, R., Eyring, V., Faluvegi, G., Folberth, G. A., Josse, B., Lee, Y. H., MacKenzie, I. A., Nagashima, T., van Noije, T. P. C., Plummer, D. A., Righi, M., Rumbold, S. T., Skeie, R., Shindell, D. T., Stevenson, D. S., Strode, S., Sudo, K., Szopa, S., and Zeng, G.: Preindustrial to present-day changes in tropospheric hydroxyl radical and methane lifetime from the Atmospheric Chemistry and Climate Model Intercomparison Project (ACCMIP), Atmos. Chem. Phys., 13, 5277-5298, doi:10.5194/acp13-5277-2013, 2013

Olivier, J. G. J. and Berdowski, J. J. M.: Global emissions sources and sinks, in: The Climate System, edited by: Berdowski, J., Guicherit, R., and Heij, B. J., 33-78, A. A. Balkema Publishers/Swets \& Zeitlinger Publishers, Lisse, the Netherlands, 2001.

Parrington, M., Jones, D. B. A., Bowman, K. W., Horowitz, L. W., Thompson, A. M., Tarasick, D. W., and Witte, J. C.: Estimating the summertime tropospheric ozone distribution over North America through assimilation of observations from the Tropospheric Emission Spectrometer, J. Geophys. Res., 113, D18307, doi:10.1029/2007JD009341, 2008.

Parrington, M., Palmer, P. I., Henze, D. K., Tarasick, D. W., Hyer, E. J., Owen, R. C., Helmig, D., Clerbaux, C., Bowman, K. W., Deeter, M. N., Barratt, E. M., Coheur, P.-F., Hurtmans, D., Jiang, Z., George, M., and Worden, J. R.: The influence of boreal biomass burning emissions on the distribution of tropospheric ozone over North America and the North Atlantic during 2010, Atmos. Chem. Phys., 12, 2077-2098, doi:10.5194/acp-12-20772012, 2012.

Pechony, O., Shindell, D. T., and Faluvegi, G.: Direct top-down estimates of biomass burning CO emissions using TES and MOPITT versus bottom-up GFED inventory, J. Geophys. Res.-Atmos., 118, 8054-8066, doi:10.1002/jgrd.50624, 2013.

Shim, C., Wang, Y., Choi, Y., Palmer, P. I., Abbot, D. S., and Chance, K.: Constraining global isoprene emissions with Global Ozone Monitoring Experiment (GOME) formalde- hyde column measurements, J. Geophys. Res., 110, D24301, doi:10.1029/2004JD005629, 2005.

Shindell, D. T., Faluvegi, G., Stevenson, D. S., Krol, M. C., Emmons, L. K., Lamarque, J. F., Pétron, G., Dentener, F. J., Ellingsen, K., Schultz, M. G., Wild, O., Amann, M., Atherton, C. S., Bergmann, D. J., Bey, I., Butler, T., Cofala, J., Collins, W. J., Derwent, R. G., Doherty, R. M., Drevet, J., Eskes, H. J., Fiore, A. M., Gauss, M., Hauglustaine, D. A., Horowitz, L. W., Isaksen, I. S. A., Lawrence, M. G., Montanaro, V., Müller, J. F., Pitari, G., Prather, M. J., Pyle, J. A., Rast, S., Rodriguez, J. M., Sanderson, M. G., Savage, N. H., Strahan, S. E., Sudo, K., Szopa, S., Unger, N., van Noije, T. P. C., and Zeng, G.: Multimodel simulations of carbon monoxide: Comparison with observations and projected near-future changes, J. Geophys. Res., 111, D19306, 10.1029/2006JD0071002006.

Singh, K., Jardak, M., Sandu, A., Bowman, K., Lee, M., and Jones, D.: Construction of non-diagonal background error covariance matrices for global chemical data assimilation, Geosci. Model Dev., 4, 299-316, doi:10.5194/gmd-4-299-2011, 2011.

Valin, L. C., Russell, A. R., Hudman, R. C., and Cohen, R. C.: Effects of model resolution on the interpretation of satellite $\mathrm{NO}_{2}$ observations, Atmos. Chem. Phys., 11, 11647-11655, doi:10.5194/acp-11-11647-2011, 2011.

van der Werf, G. R., Randerson, J. T., Giglio, L., Collatz, G. J., Mu, M., Kasibhatla, P. S., Morton, D. C., DeFries, R. S., Jin, Y., and van Leeuwen, T. T.: Global fire emissions and the contribution of deforestation, savanna, forest, agricultural, and peat fires (19972009), Atmos. Chem. Phys., 10, 11707-11735, doi:10.5194/acp10-11707-2010, 2010.

Verstraeten, W. W., Boersma, K. F., Zörner, J., Allaart, M. A. F., Bowman, K. W., and Worden, J. R.: Validation of six years of TES tropospheric ozone retrievals with ozonesonde measurements: implications for spatial patterns and temporal stability in the bias, Atmos. Meas. Tech., 6, 1413-1423, doi:10.5194/amt-61413-2013, 2013.

Vestreng, V. and Klein, H.: Emission data reported to UNECE/EMEP, Quality assurance and trend analysis and Presentation of WebDab, Norwegian Meteorological Institute, Oslo, Norway, MSC-W Status Report, 2002.

Voulgarakis, A., Telford, P. J., Aghedo, A. M., Braesicke, P., Faluvegi, G., Abraham, N. L., Bowman, K. W., Pyle, J. A., and Shindell, D. T.: Global multi-year $\mathrm{O}_{3}-\mathrm{CO}$ correlation patterns from models and TES satellite observations, Atmos. Chem. Phys., 11, 5819-5838, doi:10.5194/acp-11-5819-2011, 2011.

Walker, T. W., Martin, R. V., van Donkelaar, A., Leaitch, W. R., MacDonald, A. M., Anlauf, K. G., Cohen, R. C., Bertram, T. H., Huey, L. G., Avery, M. A., Weinheimer, A. J., Flocke, F. M., Tarasick, D. W., Thompson, A. M., Streets, D. G., and Liu, X.: TransPacific transport of reactive nitrogen and ozone to Canada during spring, Atmos. Chem. Phys., 10, 8353-8372, doi:10.5194/acp10-8353-2010, 2010.

Wang, Y. X., McElroy, M. B., Jacob, D. J., and Yantosca, R. M.: A nested grid formulation for chemical transport over Asia: applications to CO, J. Geophys. Res., 109, D22307, doi:10.1029/2004JD005237, 2004.

Wang, Y., Konopka, P., Liu, Y., Chen, H., Müller, R., Plöger, F., Riese, M., Cai, Z., and Lü, D.: Tropospheric ozone trend over Beijing from 2002-2010: ozonesonde measurements 
and modeling analysis, Atmos. Chem. Phys., 12, 8389-8399, doi:10.5194/acp-12-8389-2012, 2012.

Wild, O., Fiore, A. M., Shindell, D. T., Doherty, R. M., Collins, W. J., Dentener, F. J., Schultz, M. G., Gong, S., MacKenzie, I. A., Zeng, G., Hess, P., Duncan, B. N., Bergmann, D. J., Szopa, S., Jonson, J. E., Keating, T. J., and Zuber, A.: Modelling future changes in surface ozone: a parameterized approach, Atmos. Chem. Phys., 12, 2037-2054, doi:10.5194/acp-12-20372012, 2012.

Worden, H. M., Logan, J. A., Worden, J. R., Beer, R., Bowman, K., Clough, S. A., Eldering, A., Fisher, B. M., Gunson, M. R., Herman, R. L., Kulawik, S. S., Lampel, M. C., Luo, M., Megretskaia, I. A., Osterman, G. B., and Shephard, M. W.: Comparisons of Tropospheric Emission Spectrometer (TES) ozone profiles to ozonesondes: methods and initial results, J. Geophys. Res., 112, D03309, doi:10.1029/2006JD007258, 2007.

Worden, H. M., Deeter, M. N., Edwards, D. P., Gille, J. C., Drummond, J. R., and Neìdeìlec, P.: Observations of near surface carbon monoxide from space using MOPITT multispectral retrievals, J. Geophys. Res., 115, D18314, doi:10.1029/2010JD014242, 2010.

Worden, J., Wecht, K., Frankenberg, C., Alvarado, M., Bowman, K., Kort, E., Kulawik, S., Lee, M., Payne, V., and Worden, H.: $\mathrm{CH}_{4}$ and $\mathrm{CO}$ distributions over tropical fires during October 2006 as observed by the Aura TES satellite instrument and modeled by GEOS-Chem, Atmos. Chem. Phys., 13, 3679-3692, doi:10.5194/acp-13-3679-2013, 2013.

Yan, Y.-Y., Lin, J.-T., Kuang, Y., Yang, D., and Zhang, L.: Tropospheric carbon monoxide over the Pacific during HIPPO: two-way coupled simulation of GEOS-Chem and its multiple nested models, Atmos. Chem. Phys. Discuss., 14, 18961-18996, doi:10.5194/acpd-14-18961-2014, 2014.

Yang, Y., Liao, H., and Li, J.: Impacts of the East Asian summer monsoon on interannual variations of summertime surfacelayer ozone concentrations over China, Atmos. Chem. Phys., 14, 6867-6879, doi:10.5194/acp-14-6867-2014, 2014.
Zhang, L., Jacob, D. J., Bowman, K. W., Logan, J. A., Turquety, S., Hudman, R. C., Li, Q.- B., Beer, R., Worden, H. M., Worden, J. R., Rinsland, C. P., Kulawik, S. S., Lampel, M. C., Shephard, M. W., Fisher, B. M., Eldering, A., and Avery, M. A.: Ozone$\mathrm{CO}$ correlations determined by the TES satellite instrument in continental outflow regions, Geophys. Res. Lett., 33, L18804, doi:10.1029/2006GL026399, 2006.

Zhang, L., Jacob, D. J., Boersma, K. F., Jaffe, D. A., Olson, J. R., Bowman, K. W., Worden, J. R., Thompson, A. M., Avery, M. A., Cohen, R. C., Dibb, J. E., Flock, F. M., Fuelberg, H. E., Huey, L. G., McMillan, W. W., Singh, H. B., and Weinheimer, A. J.: Transpacific transport of ozone pollution and the effect of recent Asian emission increases on air quality in North America: an integrated analysis using satellite, aircraft, ozonesonde, and surface observations, Atmos. Chem. Phys., 8, 6117-6136, doi:10.5194/acp-8-6117-2008, 2008.

Zhang, L., Jacob, D. J., Kopacz, M., Henze, D. K., Singh, K., and Jaffe, D. A.: Intercontinental source attribution of ozone pollution at western U.S. sites using an adjoint method, Geophys. Res. Lett., 36, L11810, doi:10.1029/2009GL037950, 2009.

Zhang, Q., Streets, D. G., Carmichael, G. R., He, K. B., Huo, H., Kannari, A., Klimont, Z., Park, I. S., Reddy, S., Fu, J. S., Chen, D., Duan, L., Lei, Y., Wang, L. T., and Yao, Z. L.: Asian emissions in 2006 for the NASA INTEX-B mission, Atmos. Chem. Phys., 9, 5131-5153, doi:10.5194/acp-9-5131-2009, 2009.

Zhang, Q., Yuan, B., Shao, M., Wang, X., Lu, S., Lu, K., Wang, M., Chen, L., Chang, C.-C., and Liu, S. C.: Variations of ground-level $\mathrm{O}_{3}$ and its precursors in Beijing in summertime between 2005 and 2011, Atmos. Chem. Phys., 14, 6089-6101, doi:10.5194/acp-14-6089-2014, 2014. 